\title{
Simulation model of PID for DC-DC converter by using MATLAB
}

\author{
Salam Waley Shneen, Dina Harith Shaker, Fatin Nabeel Abdullah
}

University of Technology, Baghdad, Iraq

\begin{tabular}{|c|c|}
\hline Article Info & ABSTRACT \\
\hline Article history: & The change in loads in most applications whose source of nutrition is a \\
\hline Received Jul 31, 2020 & $\begin{array}{l}\text { renewable energy system. Renewable energy systems can change according } \\
\text { to climatic conditions. To control and control these changes, the use of }\end{array}$ \\
\hline Revised Mar 25, 2021 & conventional control systems such as PIDs. The PID is one of the most \\
\hline Accepted Apr 7, 2021 & $\begin{array}{l}\text { common and used conventional control systems that have been chosen to } \\
\text { output the type of power electronic devise (DC-DC converter) in different }\end{array}$ \\
\hline Keywords: & $\begin{array}{l}\text { working conditions. The current study aims to improve the system } \\
\text { performance through simulation. Simulation results demonstrate the }\end{array}$ \\
\hline $\begin{array}{l}\text { DC-DC converter } \\
\text { PID controller } \\
\text { PWM }\end{array}$ & $\begin{array}{l}\text { effectiveness of the system with the controller based on setting parameters } \\
\text { such as recording system states, embedded elevation time and transient } \\
\text { response. }\end{array}$ \\
\hline
\end{tabular}

This is an open access article under the CC BY-SA license.

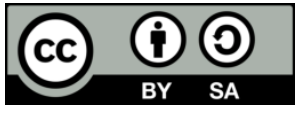

Corresponding Author:

Salam Waley Shneen

Energy and Renewable Energies Technology Center

University of Technology

52 Industry street, Baghdad, Iraq

Email: salam_waley73@yahoo.com, 50054@uotechnology.edu.iq

\section{INTRODUCTION}

Electronic power devices used in the industry work to convert energy fertile need from direct current to another. The same type may be a constant current with a change in its value and it is called DCDC, which is one of the four types of electronic power devices. Other types include another conversion of the same type of alternating current called AC-AC and the other two types, which is an alternating conversion to a continuous AC-DC or continuous to an alternating DC-AC, and it is called an inverter [1]-[5]. Power electronic devise (DC-DC converter) that convert, for example a specific electrical level of voltage to another had called constant current transformers [6]-[8]. Power electronic devise (DC-DC converter) have used in many electronic systems [9]-[11] such as power generation systems, renewable energies, communication systems and in many industrial applications [12]-[14]. Power electronic devise (DC-DC converter) are small and possess high efficiency, which gave them high reliability for use in various fields [15]-[17]. PWM works to control the converter with the adoption of tuning for traditional control systems such as PI, PD or PID.

The current work provides how to develop a design for Buck boost adapter with PWM in addition to a control unit of the type PID [18]-[20]. PID is one of the most important traditional control systems that works to control and is widely used and noticeable in the industry as it is characterized by being simple and easy to implement and applicable [21]-[23]. PID provides acceptable performance with linear systems of the first degree, the process of controlling the controller have two tasks that include setting a simple and powerful algorithm it works under suitable conditions [24]-[26]. In this work, a study and implementation of simulator performance controller for power electronic devise (DC-DC converter) with different load and source. The current simulation is using the Matlab program, which previous studies have demonstrated the possibility of using to determine the response of electronic power systems. In addition to the use of 
traditional control systems represented by PID with PWM to address the instability of different cases within the design of the system to obtain the best model with high response and short time.

\section{BUCK BOOST CONVERTER SIMULINK MODEL}

Buck boost converter Simulink model for this system include, buck boost converter Simulink model and PID for PWM.

\subsection{Buck boost converter modeling}

The simulation model as shown in Figure 1, include Vdc (24 v, $48 \mathrm{v})$, Mosfet (Ron=0.1 ohm, $\mathrm{Rd}=0.01 \mathrm{ohm} \& \mathrm{Rs}=100 \mathrm{kohm})$, diode (Ron=0.001 ohm, Vf=0.8 v, Rs=500 ohm \& Cf=250 microF), inductor $(\mathrm{L}=10 \mathrm{microH})$, capastor $(\mathrm{C}=0.5 \mathrm{mF})$ and $\operatorname{Load}(\mathrm{R}=100 \mathrm{ohm})$.



(a)



(b)

Figure 1. The simulation model of EPTs, (a) I/p =24 vdc, (b) $\mathrm{I} / \mathrm{p}=48 \mathrm{vdc}$

\subsection{PID for PWM}

The simulation model as shown in Figure 2, include PID and PWM constant (o/p voltage =100,200), Gain=(100,50), pulse $($ Amplitude $=1$, period=1/10000 \& pulse width=50) and PID Controller $(\mathrm{I}=40000)$.



(a)

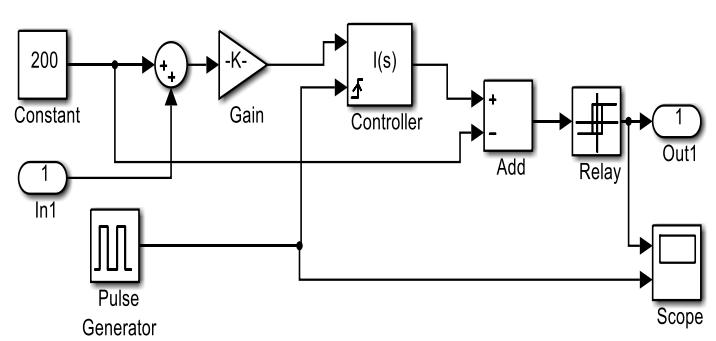

(b)

Figure 2. The simulation model PID for PWM, (a) o/p=200 vdc, (b) o/p=100 vdc

\section{RESULTS AND DISCUSSION}

The simulation results had many parts: I/p (24 vdc to $100 \mathrm{vdc}) \mathrm{o} / \mathrm{p}, \mathrm{I} / \mathrm{p}(24 \mathrm{vdc}$ to $200 \mathrm{vdc}) \mathrm{o} / \mathrm{p}$, I/p (48 vdc to $100 \mathrm{vdc})$ o/p \& I/p (48 vdc to $200 \mathrm{vdc})$ o/p at two types at Gain=50 \& 100:

\subsection{I/p (24vdc to $100 v d c)$ o/p at Gain=50 and Gain=100}

By using the simulation model in Figure 1(a) and Figure 2(a) to get the results for this part. The simulation response as shown in Figures 3 and 4, included i/p, o/p, pulse \&pulse generation:

\subsection{I/p (24vdc to 200vdc) o/p at Gain=50 and Gain=100}

By using the simulation model in Figure 1(a) and Figure 2(b) to get the results for this part. The simulation response as shown in Figures 5 and 6 , included i/p, o/p, pulse $\&$ pulse generation: 


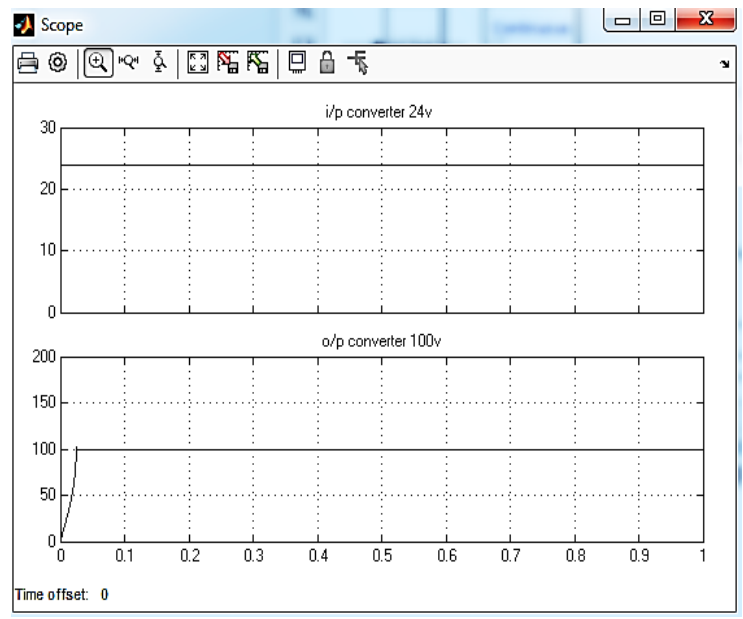

(a)



(b)

Figure 3. Simulation response of $24 \mathrm{vdc}$ to $100 \mathrm{vdc}$; (a) i/p, o/p, (b) Pulse \& pulse generation at gain 50



(a)

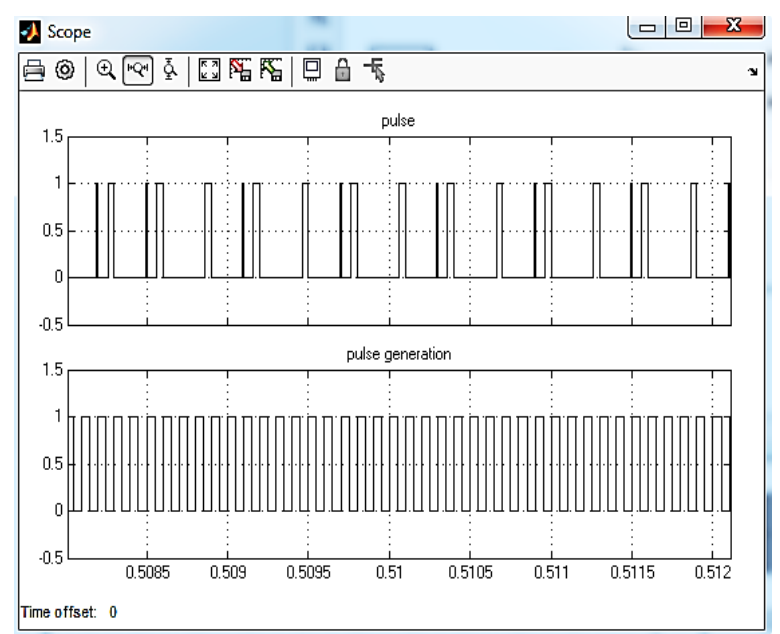

(b)

Figure 4. Simulation response of $24 \mathrm{vdc}$ to $100 \mathrm{vdc}$; (a) i/p, o/p, (b) Pulse \& pulse generation at gain 100

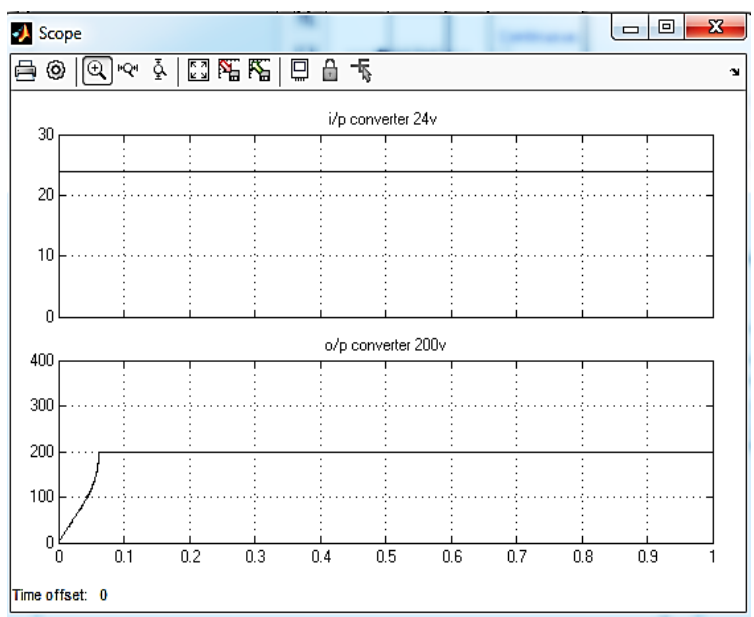

(a)

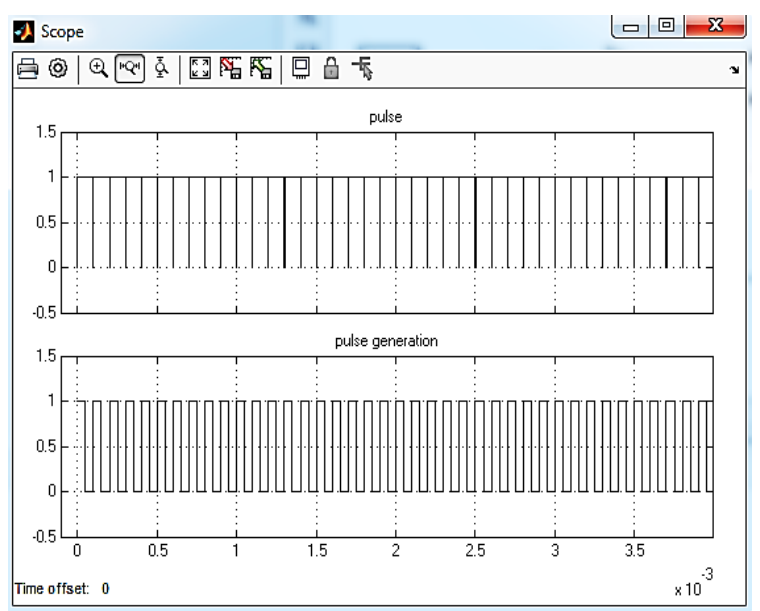

(b)

Figure 5. Simulation response of 24 vdc to $200 \mathrm{vdc}$; (a) i/p, o/p, (b) Pulse \& pulse generation at gain=50 


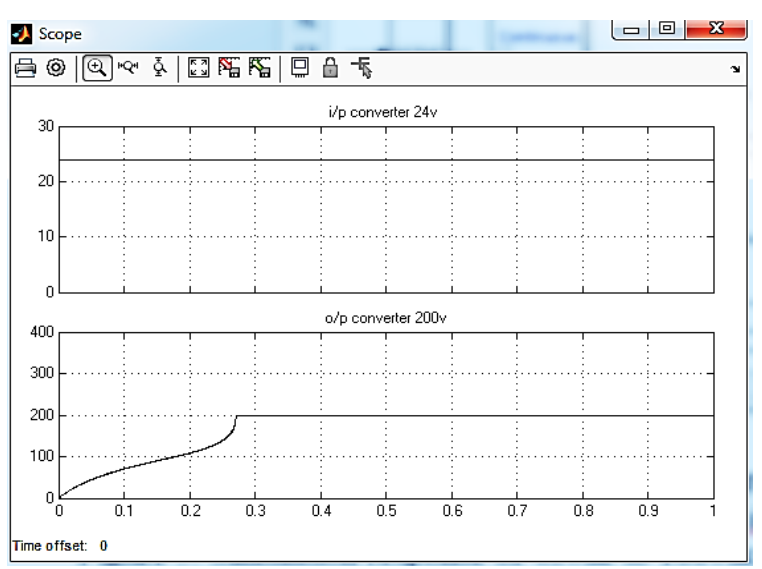

(a)



(b)

Figure 6. Simulation response of 24 vdc to $200 \mathrm{vdc}$; (a) i/p, o/p, (b) Pulse \& pulse generation at gain=100

\subsection{I/p (48vdc to $100 \mathrm{vdc}) \mathrm{o} / \mathrm{p}$ at $\mathrm{Gain}=\mathbf{5 0}$ and $\mathrm{Gain}=\mathbf{1 0 0}$}

By using the simulation model in Figure 1(b) and Figure 2(a) to get the results for this part. The simulation response as shown in Figures 7 and 8 , included $\mathrm{i} / \mathrm{p}, \mathrm{o} / \mathrm{p}$, pulse $\&$ pulse generation:



(a)

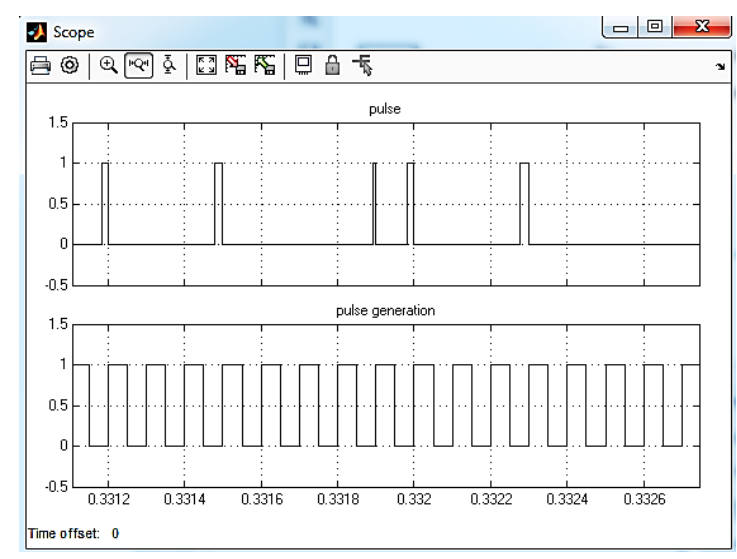

(b)

Figure 7. Simulation response of $48 \mathrm{vdc}$ to $100 \mathrm{vdc}$; (a) i/p, o/p, (b) Pulse \& pulse generation at gain=50



(a)



(b)

Figure 8. Simulation response of $48 \mathrm{vdc}$ to $100 \mathrm{vdc}$; (a) i/p, o/p, (b) Pulse \& pulse generation at gain=100 


\subsection{I/p (48vdc to $200 v d c)$ o/p at Gain $=50$ and Gain=100}

By using the simulation model in Figure 1(b) and Figure 2(b) to get the results for this part. The simulation response as shown in Figures 9 and 10, included i/p, o/p, pulse \& pulse generation:

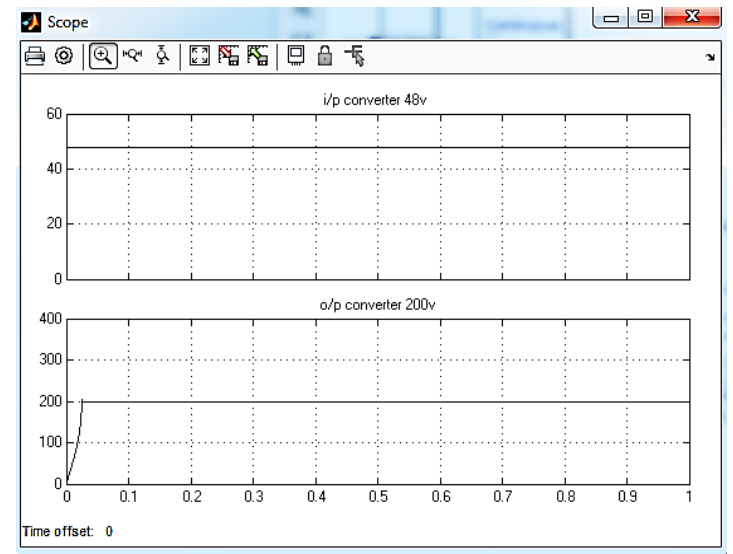

(a)



(b)

Figure 9. Simulation response of 48 vdc to $200 \mathrm{vdc}$; (a) i/p, o/p, (b) Pulse \& pulse generation at gain=50

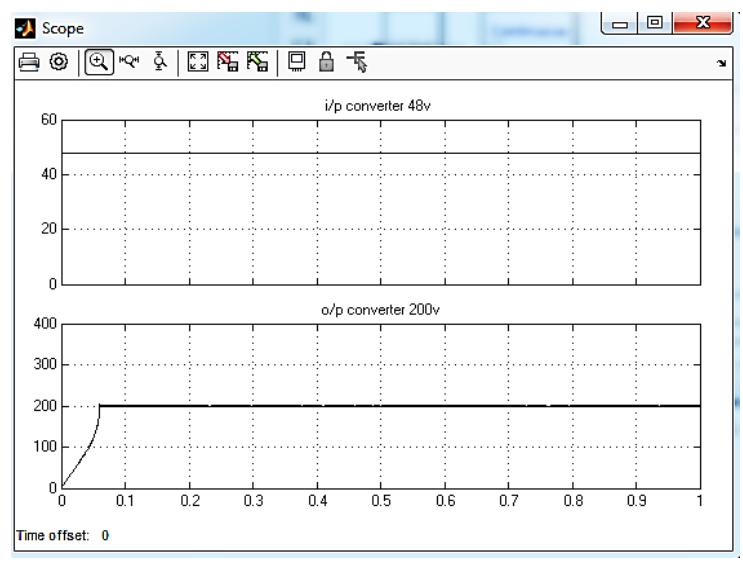

(a)

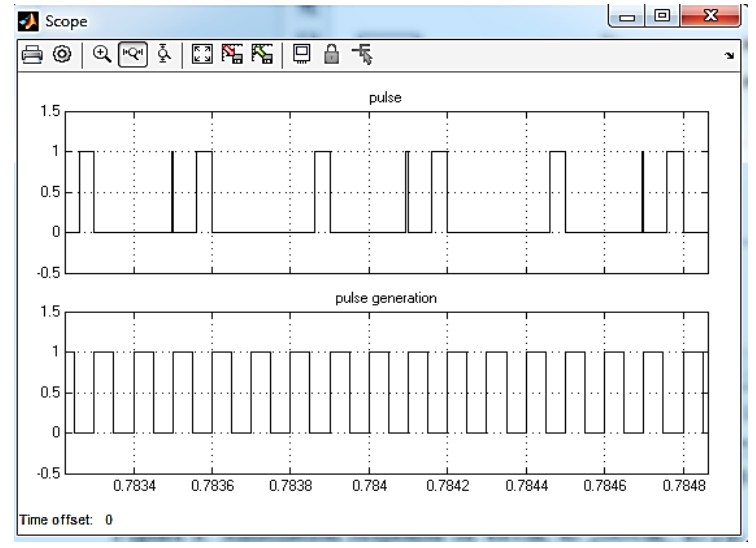

(b)

Figure 10. Simulation response of 48 vdc to $200 \mathrm{vdc}$; (a) i/p, o/p, (b) Pulse \& pulse generation at gain=100

\section{CONCLUSION AND FUTURE WORKS}

It is proposed to implement a power electronic devise (DC-DC converter) circuit within the specifications mentioned in the simulation model above. Simulation of this proposed model for voltage regulation was conducted with the aim of validating system, simulation results show that the proposed system can be used effectively in many Applications that fit the specifications of the proposed system.

It has become necessary to use the electronic converter to overcome these difficulties by controlling this important process using classic PID controllers. The process of controlling the operation of the electronic transformer begins to improve the work of the system, and this is achieved by adapting it according to the suitability of the appropriate control parameters with the position of the control system capable of adjusting the shape of its objective value of the feed. This indicates that the pattern of the surrounding areas and the system can be used to control with multiple points.

The work simulation results confirm the idea that the electronic converter has better control performance with the classic PIDC for convincing control properties. Simulation and simulation of the electronic transformer functionality was achieved by using the MATLAB software package (SIMULINK). The authors suggest using other optimization methods such as FLC with PIDC and particle swarm optimization with PIDC to learn how they affect control parameters and compare these methods with GA_PIDC to find out the best. 


\section{REFERENCES}

[1] S. N. Rao, D. V. A. Kumar, and C. S. Babu, "Grid Connected Distributed Generation System with High Voltage Gain Cascaded DC-DC Converter Fed Asymmetric Multilevel Inverter Topology," International Journal of Electrical and Computer Engineering (IJECE), vol. 8, no. 6, pp. 4047-4059, Dec. 2018, doi: 10.11591/ijece.v8i6.pp4047-4059.

[2] S. W. Shneen, "Advanced Optimal for Three Phase Rectifier in Power-Electronic Systems," Indonesian Journal of Electrical Engineering and Computer Science (IJEECS), vol.11, no. 3, pp. 821-830, 2018, doi: 10.11591/ijeecs.v11.i3.pp821-830.

[3] M. Ado, A. Jusoh, and T. Sutikno, "Extended family of DC-DC quasi-Z-source converters," International Journal of Electrical and Computer Engineering (IJEECS), vol. 9, no. 6, pp. 4540-4555, Dec. 2019, doi: 10.11591/ijece.v9i6.pp4540-4555.

[4] N. M. Radaydeh and M. R. D. Al-Mothafar, "Small-signal modeling of current-mode controlled modular DC-DC converters using the state-space algebraic approach," International Journal of Electrical and Computer Engineering (IJEECS), vol. 10, no. 1, pp. 139-150, Feb. 2020, doi: 10.11591/ijece.v10i1.pp139-150.

[5] S. W. Shneen and C. Mao, "Artificial Optimal Fuzzy Control Strategy for Elevator Drive System by Using Permanent Magnet Synchronous Motor," Indonesian Journal of Electrical Engineering and Computer Science (IJEECS), vol. 14, no. 3, pp. 470-480, Jun. 2015.

[6] Z. A. Ghani et al., "Peripheral interface controller-based maximum power point tracking algorithm for photovoltaic DC to DC boost controller," TELKOMNIKA Telecommunication Computing Electronics and Control, vol. 18, no. 1, pp. 240-250, Feb. 2020, doi: 10.11591/telkomnika.v14i3.7952.

[7] M. W. Umar, N. Yahaya, and Z. Baharudin, "State-space averaged modeling and transfer function derivation of DC-DC boost converter for high-brightness led lighting applications," TELKOMNIKA Telecommunication Computing Electronics and Control, vol. 17, no. 2, pp. 1006-1013, 2019, doi: 10.12928/TELKOMNIKA.v17i2.10272.

[8] S. W. Shneen, M. Q. Sulttan, and M. H. Jaber, "Variable speed control for 2Ph-HSM in RGS: a comparative simulation study," International Journal of Electrical and Computer Engineering (IJECE), vol. 10, no. 3, pp. 2285-2295, Jun. 2020, doi: 10.11591/ijece.v10i3.pp2285-2295.

[9] G. G. R. Sekhar and B. Banakar, "Solar PV fed non-isolated DC-DC converter for BLDC motor drive with speed control," Indonesian Journal of Electrical Engineering and Computer Science (IJEECS), vol. 13, no. 1, pp. 313-323, 2019.

[10] S. W. Shneen, F. N. Abdullah, and D. H. Shaker, "Simulation model of single phase PWM inverter by using MATLAB/Simulink," International Journal of Power Electronics and Drive Systems (IJPEDS), vol. 12, no. 1, pp. 212-216, 2021.

[11] S. W. Shneen, H. S. Dakheel, and Z. B. Abdulla, "Design and implementation of variable and constant load for induction motor," International Journal of Power Electronics and Drive Systems (IJPEDS), vol. 11, no. 2, pp. 762-773, Jun. 2020, doi: 10.11591/ijpeds.v11.i2.pp762-773.

[12] M. Z. Zulkifli, M. Azri, A. Alias, N. Talib, and J. M. Lazi, "Simple control scheme buck-boost DC-DC converter for standalone PV application system," International Journal of Power Electronics and Drive Systems (IJPEDS), vol. 10, no. 2, pp. 1090-1101, Jun. 2019, doi: 10.11591/ijpeds.v10.i2.pp1090-1101.

[13] S. W. Shneen, A. Z. Salman, Q. A. Jawad, and H. Shareef, "Advanced optimal by PSO-PI for DC motor," Indonesian Journal of Electrical Engineering and Computer Science (IJEECS), vol. 16, no. 1, pp. 165-175, 2019, doi: 10.11591/ijeecs.v16.i1.pp165-175

[14] C. S. Purohit, M. Geetha, P. Sanjeevikumar, P. K. Maroti, S. Swami, and V. K. Ramachandaramurthy, "Performance analysis of DC/DC bidirectional converter with sliding mode and pi controller," International Journal of Power Electronics and Drive Systems (IJPEDS), vol. 10, no. 1, pp. 357-365, 2019, doi: 10.11591/ijpeds.v10.i1.pp357-365.

[15] H. K. Khleaf, A. K. Nahar, and A. S. Jabbar, "Intelligent control of DC-DC converter based on PID-neural network," International Journal of Power Electronics and Drive Systems (IJPEDS), vol. 10, no. 4, pp. 2254-2262, Dec. 2019, doi: 10.11591/ijpeds.v10.i4.pp2254-2262.

[16] I. Alhamrouni, M. K. Rahmat, F. A. Ismail, M. Salem, A. Jusah, and T. Sutikno, "Design and development of SEPIC DC-DC boost converter for photovoltaic application," International Journal of Power Electronics and Drive Systems (IJPEDS), vol. 10, no. 1, pp. 406-413, 2019, doi: 10.11591/ijpeds.v10n1.pp406-413.

[17] A. J. Attiya, S. W. Shneen, B. A. Abbas, and Y. Wenyu, "Variable Speed Control Using Fuzzy-PID Controller for Two-phase Hybrid Stepping Motor in Robotic Grinding," Indonesian Journal of Electrical Engineering and Computer Science (IJEECS), vol. 3, no. 1, pp. 102-118, 2016.

[18] O. A. Trujillo, N. Toro-García, and F. E. Hoyos, "PID controller using rapid control prototyping techniques," International Journal of Electrical and Computer Engineering (IJECE), vol. 9, no. 3, pp. 1645-1655, 2019, doi: 10.11591/ijece.v9i3.pp1645-1655.

[19] S. W. Shneen, C. Mao, and D. Wang, "Advanced optimal PSO, Fuzzy and PI controller with PMSM and WTGS at $5 \mathrm{~Hz}$ side of generation and $50 \mathrm{~Hz}$ Side of Grid," International Journal of Power Electronics and Drive Systems (IJPEDS), vol. 7, no. 1, pp. 173-192, Mar. 2016.

[20] A. Uthman and S. Sudin, "Antenna Azimuth Position Control System using PID Controller and State-Feedback Controller Approach," International Journal of Electrical and Computer Engineering (IJECE), vol. 8, no. 3, pp. 1539-1550, Jun. 2018. 
[21] P. K. Kashyap and S. Kumar, "Genetic-fuzzy based load balanced protocol for WSNs," International Journal of Electrical and Computer Engineering (IJECE), vol. 9, no. 2, pp. 1168-1183, 2019, doi: 10.11591/ijece.v9i2.pp1168-1183.

[22] S. W. Shneen, "Advanced Optimal for PV system coupled with PMSM," Indonesian Journal of Electrical Engineering and Computer Science (IJEECS), vol. 1, no. 3, pp. 556-565, 2016, doi: 10.11591/ijeecs.v1.i3.pp556565.

[23] I. Zubeiri, Y. E. Morabit, and F. Mrabti, "Genetic algorithm for vertical handover (GAfVH) in a heterogeneous network," International Journal of Electrical and Computer Engineering (IJECE), vol. 9, no. 4, pp. 2534-2540, Aug. 2019, doi: 10.11591/ijece.v9i4.pp2534-2540.

[24] W. K. Wibowo and S. K. Jeong, "Genetic algorithm tuned PI controller on PMSM simplified vector control," Journal of Central South University, vol. 20, no. 11, pp. 3042-3048, 2013, doi: 10.1007/s11771-013-1827-x.

[25] S. Y Zhang and X. M. Wang, "MATLAB/Simulink, Model, Simulation, Two-Phase Hybrid Stepping Motor," in Applied Mechanics and Materials, vol. 341-341, pp. 664-667, Jul. 2013.

[26] V. Chopra, S. K. Singla, and L. Dewan, "Comparative analysis of tuning a PID controller using intelligent methods," ACTA Polytechnica hungarica, vol. 11, no. 8, pp. 235-249, 2014. 